\title{
SEROPREVALENCE OF HEPATITIS B VIRUS SURFACE ANTIGEN IN PREGNANT WOMEN ATTENDING ANC CLINIC IN A TERTIARY CARE HOSPITAL IN WEST BENGAL
}

\author{
Mohua Bose ${ }^{1}$, Ranjan Basu², Manash Sarkar ${ }^{3}$
}

${ }_{1}^{1}$ Associate Professor, Department of Microbiology, Murshidabad Medical College and Hospital, Berhampore, West Bengal, India. ${ }^{2}$ Assistant Professor, Department of Microbiology, Murshidabad Medical College and Hospital, Berhampore, West Bengal, India. 3 Professor and HOD, Department of Microbiology, Murshidabad Medical College and Hospital, Berhampore, West Bengal, India. ABSTRACT

\section{BACKGROUND}

Hepatitis B virus infection is a major public health problem worldwide. Pregnant women are a vulnerable group with a risk of transmitting the virus to the newborn if the mother is infected resulting in the risk of developing chronic infection and car rier state in the infants in later life. Effective strategies for reducing the incidence of chronic infection include screening of antenatal mothers combined with administration of HBV vaccination and immunoglobulin, immediately after birth to all children born to Hepatitis $B$ surface antigen (HBsAg) positive mothers. HBsAg is the first serological marker of active HBV infection. Thus, screening of pregnant mothers for HBsAg would help in identifying mothers at risk of transmitting the infection to infants.

\section{MATERIALS AND METHODS}

In this study of six months duration, 540 pregnant women attending the Antenatal Care (ANC) clinic were included in the study after informed consent. Thorough history was taken regarding their age, area of residence, gravidity, gestational age and his tory of jaundice. Serum samples collected from the women were tested for the presence of HBsAg using qualitative solid phase, two-site sandwich immunoassay method.

\section{RESULTS}

It was observed that the highest number of women attending the ANC clinic was in the age group of 16 - 20 years (58.89\%). It was seen that $71.11 \%$ of the pregnant mothers were from rural Bengal. $54.44 \%$ of the women were primigravidae and the highest number of women (56.67\%) visited the clinic during the 1 st trimester. Most of the attendees had no previous history of jaundice (78.89\%). It was found that 6 of the 540 women (1.11\%) were positive for HBsAg, of which 3 were in the age group of $26-30$ years.

\section{CONCLUSION}

Screening of pregnant mothers for HBV infection is an effective strategy to reduce the risk of vertical transmission by giving timely post exposure prophylaxis consisting of vaccine and immunoglobulin to the neonates born to infected mothers. The prevention of transmission in this age group helps in decreasing the overall carrier rate and in preventing another generation from being chronically infected by the virus.

\section{KEY WORDS}

HBsAg, Pregnant Mothers, Vertical Transmission, Chronic Infection.

HOW TO CITE THIS ARTICLE: Bose M, Basu R, Sarkar M. Seroprevalence of hepatitis B virus surface antigen in pregnant women attending ANC clinic in a tertiary care hospital in West Bengal. J. Evolution Med. Dent. Sci. 2018;7(26):2977-2981, DOI: $10.14260 /$ jemds/2018/671

\section{BACKGROUND}

Hepatitis $\mathrm{B}$ virus (HBV) infection is a major public health problem worldwide. It is estimated that $>2$ billion people have been infected with HBV worldwide, of which about 360 million people remain chronically infected.(1) Recent estimates of the number of individuals chronically infected with HBV have ranged from 240 million(2) to 350 million.(3) HBV infection can lead to a wide spectrum of clinical manifestations ranging from asymptomatic carrier state to acute self-limiting infections or fulminant hepatic failure, chronic hepatitis with progression to cirrhosis and hepatocellular carcinoma.(4)

'Financial or Other Competing Interest': None.

Submission 11-05-2018, Peer Review 08-06-2018,

Acceptance 14-06-2018, Published 25-06-2018.

Corresponding Author:

Dr. Mohua Bose,

AL 210, Sector 2, Salt Lake City,

Kolkata, West Bengal, India.

E-mail:mohuabapi@yahoo.com

DOI: $10.14260 /$ jemds $/ 2018 / 671$
The prevalence of HBV infection is highly variable in different parts of the world. The World Health Organisation (WHO) has classified HBV prevalence into high endemicity (>8\%), intermediate endemicity ( $2-7 \%$ ) and low endemicity $(<2 \%)$. HBV prevalence in India is in the intermediate range. In India about 100000 people die due to HBV infection related illnesses every year.(5)

The Hepatitis B virus may be transmitted parenterally, vertically from infected mother to infant, by sexual contact and by injectable drug use.(6) Pregnant women are a vulnerable group and there is a risk of transmitting infection to the newborn if the mother is infected. Infection can be transmitted from mother to infant transplacentally during pregnancy, perinatally during delivery or postnatally through breast milk.(7,8,9) $10-20 \%$ of HBsAg positive mothers can transmit the virus to the neonates, in the absence of immunoprophylaxis.(10) Foetal and neonatal hepatitis acquired from mother during pregnancy can lead to impaired cognitive and physical development in children in later life.(11) Earlier the exposure, greater is the risk of progression to chronic infection. Upto $90 \%$ of babies born to carrier 
mothers become carriers and are at a very high risk of developing chronic liver diseases at a younger age and they are the most important reservoirs of infection in the community.(12,13) Thus, prevention of transmission of infection in this group would be helpful in decreasing the overall carrier rate. Effective strategies for reducing the incidence of chronic infection include screening of antenatal mothers combined with post exposure prophylaxis consisting of HBV vaccination immediately after birth in all children born to HBsAg positive mothers, ideally along with immunoglobulin prophylaxis.(14)

Hepatitis B surface antigen (HBsAg) also known as Australia Antigen is the first serological marker of active HBV infection.(15) It is also a major serological marker of Hepatitis $B$ virus (HBV) infection. Thus, screening of pregnant mothers for HBsAg in serum would help to identify mothers at risk of transmitting the infection to infant and thus provide an opportunity to prevent the infection in the newborn by effective prophylaxis and therefore prevent the baby from being chronically infected. Also screening of pregnant mothers may indirectly help the healthcare providers as they can use universal precautions when handling such patients.

We hereby undertake a study to determine the seroprevalence of HBsAg in pregnant mothers attending the ANC clinic of our hospital.

\section{Aims and Objectives}

The study was undertaken to determine the prevalence of HBsAg positivity among the pregnant mothers attending the ANC clinic and its future implications.

\section{MATERIALS AND METHODS}

This cross-sectional study was conducted in the Department of Microbiology at Murshidabad Medical College and Hospital, a tertiary care teaching hospital in West Bengal for a period of six months from August 2016 to January 2017.

Pregnant mothers attending the ANC clinic for routine antenatal check-up within the age of 16 to 35 years, who agreed to participate were included in the study. Those mothers who gave a history of immunisation with Hepatitis B virus vaccine were excluded from the study to avoid bias. Also, mothers with any complications were excluded from the study. A total of 540 pregnant mothers were included in the study. The sample size was chosen according to our convenience keeping in mind the feasibility in our set-up regarding counselling, history taking and serum sample collection. After proper counselling and taking informed consent, a detailed history was taken from them regarding their age, area of residence, gravidity, gestational age and any history of jaundice. Serum samples collected from the women were then tested for the presence of HBsAg using qualitative solid phase, two-site sandwich immunoassay method (ASPEN HBsAg Rapid Test Cassette) following the instructions provided by the manufacturer. All samples giving positive results were retested twice before marking them as positive. Doubtful and indeterminate results were excluded from the analysis. All mothers who tested negative for HBsAg were advised hepatitis B vaccine after delivery. All newborns of mothers who tested positive for HBsAg were given both active and passive immunisation within 12 hours of delivery.
RESULTS

\begin{tabular}{|c|c|c|}
\hline $\begin{array}{c}\text { No. of } \\
\text { Attendants }\end{array}$ & $\begin{array}{c}\text { No. of Cases Positive } \\
\text { for HBsAg } \\
\text { (Australia Antigen) }\end{array}$ & $\begin{array}{c}\text { Seroprevalence } \\
\text { (Positive/n x 100) }\end{array}$ \\
\hline 540 & 6 & $1.11 \%$ \\
\hline Table 1. Results of HBsAg testing among ANC Attendants \\
$(\mathrm{n}=540)$
\end{tabular}

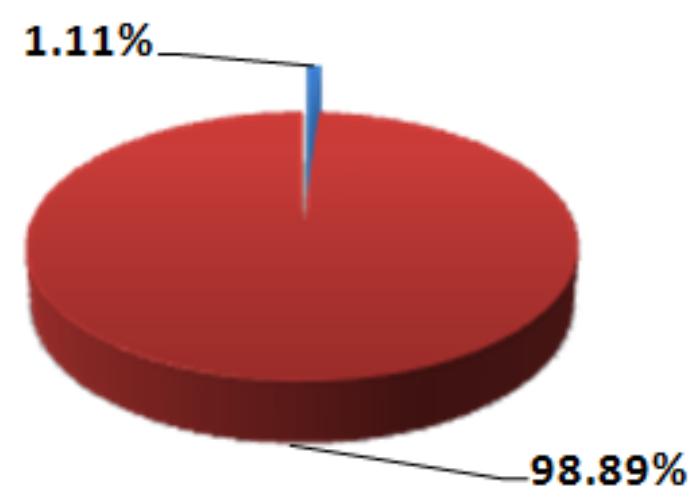

Positive Cases

Negative Cases

Figure 1. Diagram showing Results of HBsAg testing among ANC Attendants

\begin{tabular}{|c|c|c|c|}
\hline Age Group & $\begin{array}{c}\text { No. of the } \\
\text { ANC } \\
\text { Attendants }\end{array}$ & $\begin{array}{c}\text { No. of the ANC } \\
\text { Attendants } \\
\text { Positive for } \\
\text { HBsAg }\end{array}$ & $\begin{array}{c}\text { Sero } \\
\text { prevalence of } \\
\text { HBsAg }\end{array}$ \\
\hline $16-20$ & $\begin{array}{c}318 \\
(58.89 \%)\end{array}$ & 1 & $0.31 \%$ \\
\hline $21-25$ & $186(34.44 \%$ & 1 & $0.54 \%$ \\
\hline $26-30$ & $24(4.44 \%)$ & 3 & $12.5 \%$ \\
\hline $31-35$ & $12(2.22 \%)$ & 1 & $8.3 \%$ \\
\hline Total & $\mathbf{5 4 0}$ & $\mathbf{6}$ & $\mathbf{1 . 1 1 \%}$ \\
\hline
\end{tabular}

Table 2. Age Wise distribution of the ANC attendants along with Seroprevalence of HBsAg

It was observed that the highest number of pregnant women attending the ANC clinic was in the age group of 1620 yrs. (58.89\%) and the lowest number was in the age group of 31 - 35 years $(2.22 \%)$. Highest prevalence was found in the age group of 26 - 30 years.

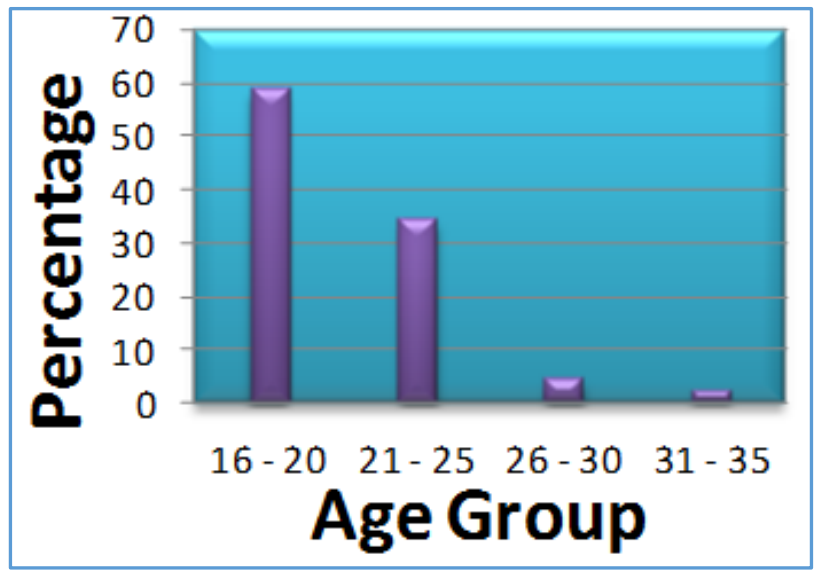

Figure 2. Bar Diagram showing the Age Wise distribution of the ANC attendees included in the Study 


\begin{tabular}{|c|c|c|c|}
\hline $\begin{array}{c}\text { Area of } \\
\text { Residence }\end{array}$ & $\begin{array}{c}\text { No. of the } \\
\text { ANC } \\
\text { Attendants }\end{array}$ & $\begin{array}{c}\text { No. of the ANC } \\
\text { Attendants } \\
\text { Positive for } \\
\text { HBsAg }\end{array}$ & $\begin{array}{c}\text { Sero-pre- } \\
\text { valence } \\
\text { of HBsAg }\end{array}$ \\
\hline Rural & $384(71.11 \%)$ & 4 & $1.04 \%$ \\
\hline Urban & $156(28.89 \%)$ & 2 & $1.28 \%$ \\
\hline Total & $\mathbf{5 4 0}$ & $\mathbf{6}$ & $\mathbf{1 . 1 1 \%}$ \\
\hline
\end{tabular}

Table 3. Area Wise distribution of the ANC attendees along with seroprevalence of HBsAg among them. It was seen that $71.11 \%$ of the pregnant mothers were from rural Bengal. Seroprevalence was higher in the Urban Residents though the number was Less (2), as the percentage of the Urban Residents were also Less (28.89\%)

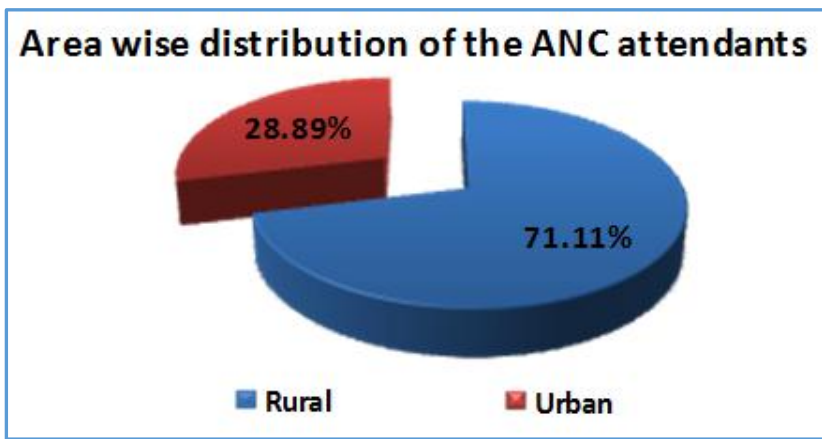

Figure 3. Diagram showing Area Wise distribution of the ANC Attendants

\begin{tabular}{|c|c|c|c|}
\hline Gravidity & $\begin{array}{l}\text { No. of the ANC } \\
\text { Attendants }\end{array}$ & \begin{tabular}{|c|} 
No. of the ANC \\
Attendants \\
Positive for \\
HBsAg
\end{tabular} & $\begin{array}{c}\text { Sero- } \\
\text { prevalence } \\
\text { of HBsAg }\end{array}$ \\
\hline Primigravida & $294(54.44 \%)$ & 2 & $0.68 \%$ \\
\hline Multigravida & $246(45.56 \%)$ & 4 & $1.63 \%$ \\
\hline Total & 540 & 6 & $1.11 \%$ \\
\hline \multicolumn{4}{|c|}{$\begin{array}{l}\text { Table 4. Gravidity of the ANC attendants along with } \\
\text { seroprevalence of HBsAg among them. Higher } \\
\text { seroprevalence was seen in the Multigravidae (1.63\%). }\end{array}$} \\
\hline
\end{tabular}

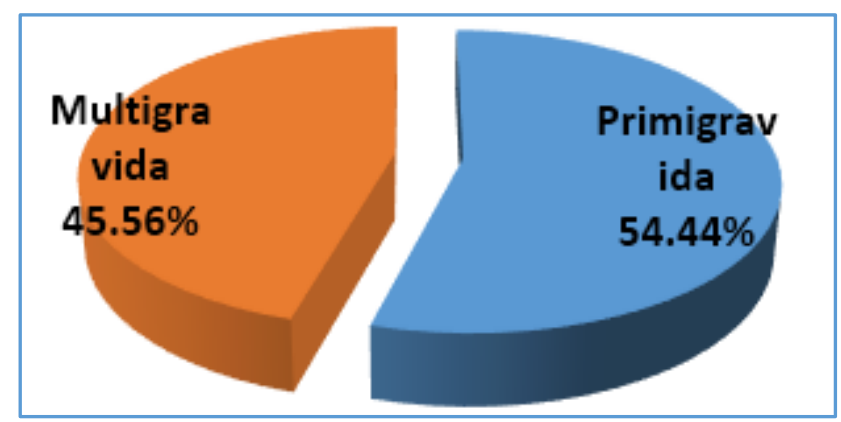

Figure 4. Diagram showing Gravidity of the ANC Attendants

\begin{tabular}{|c|c|c|c|}
\hline Time & $\begin{array}{l}\text { No. of the } \\
\text { ANC } \\
\text { Attendants }\end{array}$ & $\begin{array}{l}\text { No. of the ANC } \\
\text { Attendants } \\
\text { Positive for } \\
\text { HBsAg }\end{array}$ & $\begin{array}{c}\text { Seroprevalence } \\
\text { of HBsAg }\end{array}$ \\
\hline $1^{\text {st }}$ Trimester & $\begin{array}{c}306 \\
(56.67 \%)\end{array}$ & 2 & $0.65 \%$ \\
\hline $2^{\text {nd }}$ Trimester & $\begin{array}{c}72 \\
(13.33 \%)\end{array}$ & 1 & $1.39 \%$ \\
\hline 3rd Trimester & $162(30 \%)$ & 3 & $1.85 \%$ \\
\hline Total & 540 & 6 & $1.11 \%$ \\
\hline \multicolumn{4}{|c|}{\begin{tabular}{|c|} 
Table 5. Gestational Age of the Pregnant Mothers at the \\
time of attending the ANC clinic along with seroprevalence \\
of HBsAg among them. Highest seroprevalence was seen in \\
Mothers attending during the $3^{\text {rd }}$ Trimester
\end{tabular}} \\
\hline
\end{tabular}

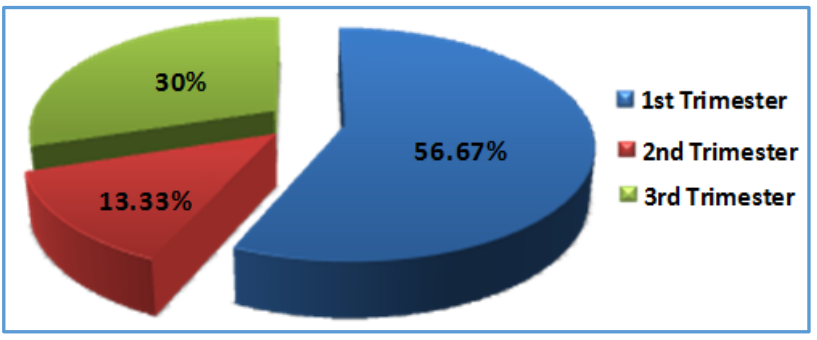

Figure 5. Diagram showing Gestational Age of the Pregnant Mothers at the time of attending the ANC Clinic

\begin{tabular}{|c|c|c|c|}
\hline $\begin{array}{l}\text { Presence of } \\
\text { Jaundice }\end{array}$ & $\begin{array}{l}\text { No. of the } \\
\text { ANC } \\
\text { Attendants }\end{array}$ & \begin{tabular}{|c|} 
No. of the ANC \\
Attendants \\
Positive for \\
HBsAg
\end{tabular} & $\begin{array}{c}\text { Sero- } \\
\text { prevalenc } \\
\text { of HBsAg }\end{array}$ \\
\hline $\begin{array}{c}\text { Before } \\
\text { Pregnancy }\end{array}$ & 60 (11.11\%) & 5 & $8.3 \%$ \\
\hline $\begin{array}{c}\text { During } \\
\text { Pregnancy }\end{array}$ & $54(10 \%)$ & 1 & $1.85 \%$ \\
\hline $\begin{array}{l}\text { Patient without } \\
\text { any history of } \\
\text { jaundice }\end{array}$ & 426 (78.89\%) & 0 & 0 \\
\hline Total & 540 & 6 & $1.11 \%$ \\
\hline \multicolumn{4}{|c|}{$\begin{array}{c}\text { Table 6. Status of Jaundice of the ANC attendants along } \\
\text { with seroprevalence of HBsAg among them }\end{array}$} \\
\hline $78.89 \%$ & & $\begin{array}{l}\square \text { Before Pre } \\
\square \text { During Pre } \\
\% \\
\text { Patient wi } \\
\text { history of }\end{array}$ & $\begin{array}{l}\text { eganacy } \\
\text { egnancy } \\
\text { ithout any } \\
\text { jaundice }\end{array}$ \\
\hline
\end{tabular}

Figure 6. Status of Jaundice of the ANC attendants included in the Study

\begin{tabular}{|c|c|c|}
\hline Age Group & No. of the ANC Attendants & Seroprevalence \\
\hline $16-20$ & 1 & $16.66 \%$ \\
\hline $21-25$ & 1 & $16.66 \%$ \\
\hline $26-30$ & 3 & $50 \%$ \\
\hline $31-35$ & 1 & $16.66 \%$ \\
\hline Table 7. Age Wise distribution of the Hepatitis B Surface \\
Antigen Positive Cases (n=540) \\
\hline
\end{tabular}

It was observed that the highest prevalence was in the age group of $26-30$ years $(50 \%)$ and the prevalence was equal in all other age groups.

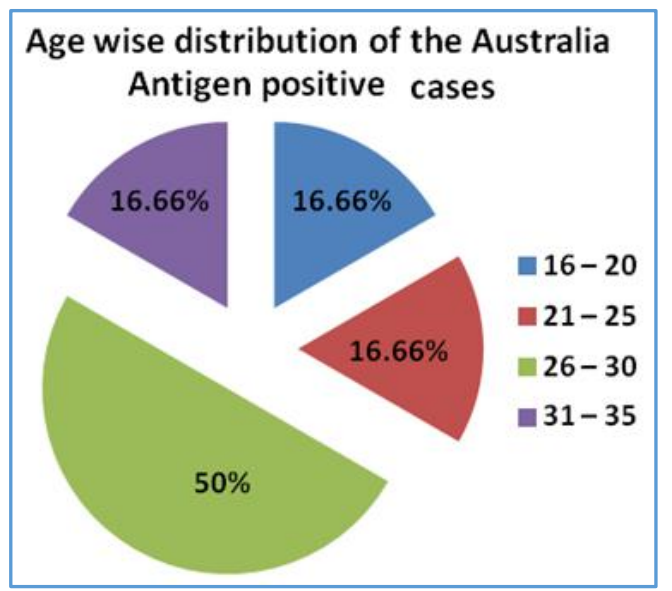

Figure 7 


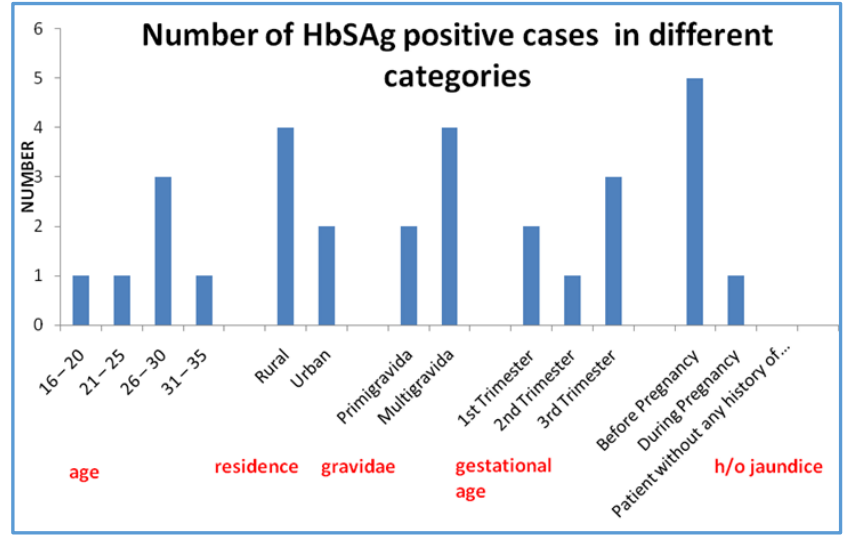

Figure 8

\section{DISCUSSION}

In the present study, the seroprevalence rate of HBsAg in pregnant women attending ANC clinic was $1.11 \%$. This correlates with the seroprevalence rate of $1.11 \%$ reported by Sibia P et al from a study in North India,(16) $1.1 \%$ by Pande et al(17) and $1.01 \%$ by Sathiyakala $\mathrm{R}$ et al from a study in South India.(18) It is also comparable to the prevalence rate in some other Indian studies like $0.9 \%$ reported by Dwivedi $\mathrm{M}$ et al ${ }^{(19)}$ and $0.82 \%$ by Chatterjee $S$ et al.(20) In a review article, Lodha $\mathrm{R}$ et al concluded that the prevalence rate in India was $1-2 \%$.(21) However, wide variations in the prevalence rate has been seen in different studies from different regions. Prakash $\mathrm{C}$ et al reported a high prevalence rate of $9.5 \%$ in a study in North India.(22) A prevalence rate of HBV among ANC attendants of $2.04 \%$ was reported by Garg $\mathrm{R}^{(23)}$ and $3.9 \%$ by Sinha A et al.(24) International studies also show wide variations. A seroprevalence of 3.9\% was reported by Rashid S et al in Tanzania,(25) $13.8 \%$ by Getahun A et al from Honiara Solomon Island(26) and $5.44 \%$ by Choisy $\mathrm{M}$ et al from Vientiane, Laos.(27) These differences in the prevalence rates may be due to geographic variation, sensitivity of the detection methods and environmental factors.

In our study $71.11 \%$ of women were from rural areas, whereas $28.89 \%$ were from urban residency. This is comparable to the study by Sibia P et al,(16) where $75.61 \%$ subjects were from rural areas and $24.39 \%$ were from urban areas. In our study $54.44 \%$ subjects were primigavidae, whereas in the study by Rashid S et al(25) only $31 \%$ were primigravidae. The most common age group of HBsAg positivity (50\%) in our study was 26 - 30 years. This correlates with the studies of Sibia P et al(16) and Sathiyakala $\mathrm{R}$ et al (46.1\%).(18) The mean age of HBsAg positivity in pregnant mothers reported by Fomulu et al(28) was 26.9 years' age group and by Vazquez-Martinez et al(29) was 26 years and by Rashid S et al(25) was 28.5 years. A higher prevalence rate in women aged twenty years and less than in older women was reported by Bayo $\mathrm{P}$ et al(30) and by Eke AC et al(31) in a Nigerian study.

The US Preventive Services Task Force found convincing evidence that screening of Antenatal mothers for HBV infection substantially reduces perinatal transmission of HBV and the subsequent development of chronic infection. (32) Infants born to HBsAg seropositive mothers should receive $0.5 \mathrm{~mL}$ Hepatitis B immunoglobulin and Hepatitis B vaccine within 12 hours of birth to prevent subsequent development of infection and a chronic carrier state.(32)

\section{CONCLUSION}

Screening of pregnant mothers for HBV infection is an effective strategy to reduce the risk of vertical transmission by giving timely post exposure prophylaxis consisting of vaccine and immunoglobulin as recommended to the neonates born to infected mothers. The prevention of transmission in this age group helps in decreasing the overall carrier rate and in preventing another generation from being chronically infected by the virus.

There are some limitations in our study. We have screened subjects only for HBsAg as a marker of HBV infection. If other markers of viral replication such as $\mathrm{HbeAg}$ and HBV DNA could be tested, then the study would have been more fruitful as presence of $\mathrm{HBeAg}$ in HBsAg positive pregnant women increases the risk of perinatal transmission. But we could not do it owing to financial constraints. Also, we used a rapid test for the detection of HBsAg, which generally has a low sensitivity that makes it unsuitable for HBsAg detection at low concentrations. ELISA test has a higher sensitivity of detection. However, in our rural set-up, ELISA for detection of HBsAg is still not available.

\section{ACKNOWLEDGEMENT}

We extend our sincere thanks to all faculty members, technical and non-technical staff of the Department of Microbiology, Murshidabad Medical College and Hospital, for all the support given by them during the work period. We also thank Ms. Priya Mandal, project worker in the department for her help. We also thank all doctors, nurses and non-technical staff in the ANC clinic of Murshidabad Medical College and Hospital for their cooperation.

\section{REFERENCES}

[1] World Health Organization. Hepatitis B vaccines. Wkly Epidemiol Rec. 2009;84:405-19.

[2] Ott JJ, Stevens GA, Groeger J, et al. Global epidemiology of hepatitis B virus infection: new estimates of agespecific HBsAg seroprevalence and endemicity. Vaccine 2012;30(12):2212-9.

[3] Lavanchy D. Hepatitis B virus epidemiology, disease burden, treatment and current and emerging prevention and control measures. J Viral Hepat 2004;11(2):97-107.

[4] Zhu R, Zhang H, Yu H, et al. Hepatitis B virus mutations associated with in situ expression of hepatitis B core antigen, viral load and prognosis in chronic hepatitis B patients. Pathol Res Pract 2008;204(10):731-42.

[5] World Health Organization. Hepatitis B. Fact sheet N 204.

http://www.who.int/mediacentre/factsheets/fs204/e $\mathrm{n} /$

[6] Lok AS, McMahon BJ. Chronic hepatitis B: update 2009. Hepatology 2009;50(3):661-2.

[7] Yan Y, Xu D, Wang W. The role of placenta in hepatitis $\mathrm{B}$ virus intrauterine transmission. Zhonghua Fu Chan Ke Za Zhi 1999;34(7):392-5.

[8] Xu D, Yan Y, Xu J. A molecular epidemiologic study on the mechanism of intrauterine transmission of hepatitis B virus. Zhonghua Liu Xing Bing Xue Za Zhi 1998;19(3):131-3. 
[9] Xu DZ, Yan YP, Zou S, et al. Role of placental tissue in the intrauterine transmission of hepatitis B virus. Am J Obstet Gynecol 2001;185(4):981-7.

[10] American College of Obstetricians and Gynecologists. ACOG Practice Bulletin No. 86: viral hepatitis in pregnancy. Obstetrics and Gynaecology 2007;110(4):941-56.

[11] Olaitan AO, Zamani LG. Prevalence of hepatitis B virus and hepatitis $\mathrm{C}$ virus in antenatal-patients in Gwagwalada-Abuja, Nigeria. Report and Opinion 2010;2(7):48-50.

[12] Joshi N, Kumar A. Immunoprophylaxis of hepatitis B virus infection. Indian J Med Microbiol 2001;19(4):172-83.

[13] Chakravarti A, Rawat D, Jain M. A study on the perinatal transmission of the hepatitis B virus. Indian J Med Microbiol 2005;23(2):128-30.

[14] Lee C, Gong Y, Brok J, et al. Effect of hepatitis B immunization in newborn infants of mothers positive for hepatitis B surface antigen: systematic review and meta-analysis. BMJ 2006;332(7537):328-36.

[15] Murray PR, Baron EJ, Jorgensen JH. The Manual of clinical microbiology. Washington D.C: ASM Press 2003: p. 1464-78.

[16] Sibia P, Mohi MK, Kumar A. Seroprevalence of Hepatitis B infection among pregnant women in one of the Institute of Northern India. Journal of Clinical and Diagnostic Research 2016;10(8):QC08-9.

[17] Pande C, Sarin SK, Patra S, et al. Prevalence, risk factors and virological profile of chronic hepatitis $B$ virus infection in pregnant women in India. J Med Virol 2011;83(6):962-7.

[18] Sathiyakala R, Ushadevi G, Karthika J. Seroprevalence of Hepatitis B infection among pregnant women in South India. Int J Reprod Contracept Obstet \& Gynecol 2017;6(1):249-51.

[19] Dwivedi M, Misra SP, Misra V, et al. Seroprevalence of hepatitis B infection during pregnancy and the risk of perinatal transmission. Indian J Gastroenterol 2011;30(2):66-71.

[20] Chatterjee S, Ravishankar K, Chaterjee R, et al. Hepatitis B prevalence during pregnancy. Indian Pediatrics 2009;46(11):1005-8.

[21] Lodha R, Jain Y, Anand K, et al. Hepatiris B in India: A review of disease epidemiology. Indian Pediatrics 2001;38(4):349-71.

[22] Prakash C, Sharma RS, Bhatia R, et al. Prevalence of North India of hepatitis B carrier state among pregnant women. Southeast Asian J Trop Med Public Health 1998;29(1):80-4.
[23] Garg R, Nigam A, Singh S, et al. Seroprevalence of Hepatitis B surface antigen among pregnant women in a tertiary care health center of North India. Journal of South Asian Federation of Obstetrics and Gynaecology 2017;9(2):164-8.

[24] Sinha A, Sharan M, Shahi SK. Seroprevalence of Hepatitis B virus in pregnant women at a tertiary care hospital of Eastern India. National Journal of Laboratory Medicine 2016:1-4.

[25] Rashid S, Kilewo C, Aboud S. Seroprevalence of hepatitis B virus infection among antenatal clinic attendees at a tertiary hospital in Dar es Salaam, Tanzania. Tanzan J Health Res 2014;16(1):9-15.

[26] Getahun A, Baekalia M, Panda N, et al. Seroprevalence of hepatitis B surface antigen in pregnant women attending antenatal clinic in Honiara Solomon Islands, 2015. World J Hepatol 2016;8(34):1521-8.

[27] Choisy M, Keomalaphet S, Xaydalasouk K, et al. Prevalence of Hepatitis $\mathrm{B}$ virus infection among pregnant women attending antenatal clinics in Vientiane, Laos, 2008-2014. Hepatitis Research and Treatment 2017;2017:1284273.

[28] Fomulu NJ, Morfaw FL, Torimiro JN, et al. Prevalence correlates and pattern of hepatitis B among antenatal clinic attendees in Yaounde-Cameroon: is perinatal transmission of HBV neglected in Cameroon? BMC Pregnancy Childbirth 2013;13(1):158.

[29] Vazquez-Martinez JL, Coreno-Juarez MO, MontanoEstrada LF, et al. Seroprevalencia de hepatitis B en mujeres embarazadas en Mexico. Salud Publica Mexico 2003;45(3):165-70.

[30] Bayo P, Ochola E, Oleo C, et al. High prevalence of hepatitis $\mathrm{B}$ virus infection among pregnant women attending antenatal care: a cross sectional study in two hospitals in Northern Uganda. BMJ Open 2014;4(11):e005889.

[31] Eke AC, Eke UA, Okafor CI, et al. Prevalence, correlates and pattern of hepatitis B surface antigen in a low resource setting. Virol J 2011;8:12.

[32] U.S. Preventive Services Task Force. Screening for Hepatitis B virus infection in pregnancy: U.S. Preventive Services Task Force reaffirmation recommendation statement. Annals of Internal Medicine 2009;150(12):869-73, W154. 